\title{
Lime and Phosphorus Rates Response on Dry Matter Production and Partitioning of Hybrid of Coffee (Coffea arabica L.) Seedlings Growth on Acidic Soil
}

\author{
Ewnetu Teshale \\ Ethiopian Institute of Agricultural Research, Jimma Agricultural Research Center, Jimma, Ethiopia
}

\section{Email address:}

ewnetu.tg@gmail.com

\section{To cite this article:}

Ewnetu Teshale. Lime and Phosphorus Rates Response on Dry Matter Production and Partitioning of Hybrid of Coffee (Coffea arabica L.) Seedlings Growth on Acidic Soil. American Journal of Heterocyclic Chemistry. Vol. 7, No. 2, 2021, pp. 1-6.

doi: 10.11648/j.ajhc.20210701.11

Received: December 25, 2020; Accepted: January 7, 2021; Published: April 20, 2021

\begin{abstract}
Coffee (Coffea arabica L.) is indigenous to the tropical rain forests of Ethiopia in the South and Southwest where there was persistent usage since ancient times. Coffee soils in the south-western parts of Ethiopia can be attributed to excessive accumulations of aluminum, iron or manganese which leads to deficiencies of phosphorus other nutrients. This low soil $\mathrm{pH}$ and nutrient deficiencies encountered in the soils of the study area are expected to decrease the growth and dry matter of coffee seedlings. Liming is more effective in combination with phosphorus fertilization or that the secondary effect of liming is higher phosphorus fertilizer availability to the coffee seedlings. The research was conducted at Jimma Agricultural Research Center, south west Ethiopia to evaluate the response of lime and phosphorus rates on coffee seedlings dry matter production and partitioning. The experiment was laid out in a randomized complete block design with 3 replications. The treatments were arranged in factorial combinations of five levels of lime $(0,5,10,15$ and $20 \mathrm{~g})$ and four levels of phosphorus $(0,400,600$ and $800 \mathrm{mg}) 2.5 \mathrm{~kg}-{ }^{1}$ top soil. The statistical data was analyzed through SAS software and treatment means were compared at $5 \%$ probability using Duncan Multiple Range Test. The results revealed that the interactions of lime and $\mathrm{P}$ rates significantly increased dry matter production, partitioning and shoot to root ratio. The maximum dry matter production, partitioning and shoot to root ratio were recorded from the interaction of $10 \mathrm{~g}$ lime and $800 \mathrm{mg} P$ rates $2.5 \mathrm{~kg}_{-}{ }^{1}$ top soil. Hence, combined application of $10 \mathrm{~g}$ lime and $800 \mathrm{mg} P$ rate $2.5 \mathrm{~kg}^{-}{ }^{1}$ top provides the optimum dry matter production, partitioning and shoot to root ratio for the growth of coffee seedlings under nursery conditions.
\end{abstract}

Keywords: Coffee Seedlings, Dry Matter, Phosphorus Rate, Soil Acidity

\section{Introductions}

In Ethiopia coffee Arabica coffee is an important export crop traded globally and is a major foreign exchange earner for the country. Ethiopia is one of the major coffee producer in Africa and is the $6^{\text {th }}$ producer in the world contributing to about $4.8 \%$ of the total world coffee production [14]. Coffea arabica is an indigenous to the tropical rain forests of Ethiopia in the South and southwest where there was persistent usage since ancient times [6-8]. Coffee can adapt to different soil types and the soil requirements for sustainable high yield of arabica coffee should be of deep profile, over about $180 \mathrm{~cm}$, moderately to heavy texture, good drainage and of high organic matter content [4-17]. It can then be inferred that the infertility of the coffee soils in the western, south-western, and southern parts of Ethiopia can be attributed to excessive accumulations of aluminum, iron and manganese causes for deficiencies in available phosphorus and basic cations [10-21]. In the high rainfall areas of western Ethiopia are strongly acidic, high in exchangeable aluminum throughout the profile, but low in CEC, exchangeable bases, available phosphorus, and organic matter [2]. Under these conditions, increased levels of lime and phosphorus application significantly correlated with many of the agronomic parameters, and that the interaction effect thereof was significant. In order to counteract the effect of soil acidity on crop growth, liming is a traditional practice often applied to soils to restore $\mathrm{Ca}$ and $\mathrm{Mg}$ 
availability for plants and adjust soil [5]. Naidu et al. [16] observed the beneficial effect of liming in reduced micronutrient toxicity while increasing the availability of $\mathrm{Ca}$, $\mathrm{P}$, Mo and $\mathrm{Mg}$ in the soil. The soil is poor in plant available soil $\mathrm{P}$ because of high P-fixing capacity. Fertilizer experiments on some crops at the area have shown that $\mathrm{P}$ is the limiting nutrients to crop production with a significant yield increase and profitable return to the application of these nutrients [17]. Thus, low soil $\mathrm{pH}$ is considered to be the main cause of yield reduction for all crops in general and acid sensitive crops in particular in the study area. This low soil $\mathrm{pH}$ and nutrient deficiencies encountered in the soils of the study area are expected to decrease the growth and dry matter of coffee seedlings. Adding lime or other materials can raise the soil $\mathrm{pH}$ to the ideal range for coffee seedlings production create an environment for the healthy functioning of microbes, and increase levels of calcium or magnesium ions. Then both soil physical and chemical conditions and the proportion of available nutrients determine coffee seedling vegetative growth and its latter health and vigorous seedlings for transplanting to main field. Hence, there is now a new interest in using chemical fertilizers in combination with lime sources with the basic concept to maintain and increase soil fertility for increased sustained crop production by optimizing all possible sources in an integrated and judicious manner within a given ecological, social and economic setting. Liming is more effective in combination with phosphorus fertilization to enhance phosphorus fertilizer availability to the optimum growth of coffee seedlings [5]. Similar benefits of lime and $\mathrm{P}$ application on crop responses and improvements of soil properties have also been reported in highly acidic soils [12]. This research activity was conducted to evaluate the response of lime and mineral phosphorus fertilizer on dry matter production and partitioning of hybrid coffee seedlings growth on acidic Nitisols soil in case of Jimma southwest Ethiopia.

\section{Material and methods}

\subsection{Descriptions of the Study Area}

The study was conducted at Jimma Agricultural Research Center coffee seedlings nursery site. The experimental soil type was Eutric nitisol. The center is geographically located between $7^{\circ} 46^{\prime} \mathrm{N}$, latitude $36^{\circ} 47^{\prime} \mathrm{E}$ longitudes at an altitude 1750 meter above sea level. The area receives mean annual rainfall of $1737 \mathrm{~mm}$ with maximum and minimum temperature of $25.21^{\circ} \mathrm{C}$ and $12.21^{\circ} \mathrm{C}$, respectively. EutricNitisols are the dominant reference soil groups in the study areas [7].

\subsection{Experimental Material, Design and Procedures}

Hybrid coffee Gawe which was highly yielding variety was used for the experiments. The treatments were arranged factorial randomized complete block design with having lime rates $(0,5,10,15$ and 20 gram) and phosphorus rates $(0,400$, 600 and $800 \mathrm{mg}$ ) per experimental pot. Lime $\mathrm{CaCo} 3$ was applied before one month of sowing time and TSP fertilizers were treated at the stage of true leaf emerged. $\mathrm{N}$ recommended fertilizer rate was applied at the stage of first leaf, second leaf and forth pair of leaf. Nursery management's practices watering, mulching, weeding were conducted according to Tesfaye [22].

\subsection{Data Collections}

The coffee seedlings were uprooted when attain at sixth pair of leaves. The stem, branches, leaves and roots were separated by cutting the plant with sharp clean knife. The vegetative parts were removed, washed, weighed and dried separately in the shade. All coffee seedlings parts leaf, stem and root were separately placed in labeled paper bag and dried oven at $70^{\circ} \mathrm{C}$ for 24 hours to a constant weight and dry matter was measured for each samples using sensitive balance. The dry matter of roots, were determined by weighing the root materials separated from the aerial part of the plant on analytical balance. The mass of dry matter of the aerial part was obtained by the sum of the weight of the dry mass of leaves, stems and branches. The total dry matter was obtained by the sum of the dry matter arial part and the dry matter roots. The dry weight of each part was used to determine the dry matter partition to stem, leaves and roots. Shoot to root ratio was determined as (stem and leaf dry matter divided to root dry matter) of the coffee seedlings [23].

\subsection{Statistical Analysis}

The data were subjected to analysis of variance (ANOVA) Statistical analysis software version 9.3 Treatment means were separated using DMRT test at (5\%) probability level

\section{Result and Discussions}

\subsection{Total Dry Matter Production}

Lime and $\mathrm{P}$ rates and their interactions significantly affected total dry matter production (Figure 1). However the maximum $0.837 \mathrm{~g}$ total dry matter was recorded from the interactions of $10 \mathrm{~g}$ lime and $800 \mathrm{mg} P$ rate. While the lowest $0.293 \mathrm{~g}$ dry mater contents of coffee seedlings recorded from higher lime rates and P $20 \mathrm{~g}$. The reduction in total dry matter content of coffee seedlings at higher lime rate attributed to a reduction in the solubility and availability of $\mathrm{P}$ to crops which might be caused by the formation of insoluble Ca-P compounds in the soil and reduced the availability of macro nutrients and P deficiency Fe, Mn, $\mathrm{Zn}$ and B deficiency [1113]. Similarly, on control plots $0.413 \mathrm{~g}$ was recorded. On control plot the major constraints to seedlings growth through increasing in the concentration of $\mathrm{H}, \mathrm{Al}$ and $\mathrm{Mn}$ and decreasing in basic cations of magnesium, calcium and potassium Moreover, it causes deficiency of $\mathrm{P}$ and molybdenum (Mo) through decreasing their solubility [1].

Additions of $5 \mathrm{~g}$ and $10 \mathrm{~g}$ lime showed 0.437 and $0.580 \mathrm{~g}$ dry matter content respectively. But the further increments leads to reduce as the lime rate increased from $15 \mathrm{~g}$ and $20 \mathrm{~g}$ which were resulted to 0.347 and $0.293 \mathrm{~g}$ dry matter content 
respectively. In line with these work Anteneh [3] reported that as the lime rate increased from the optimum level the total dry mater production decline contrary. As compared to plots which brought the highest recorded total dry matter, there was $47.22 \%$ decrement of total dry mater observed. However, Kampareth [15] and Fageria and Baligar [12] reported that heavier applications lime to the soil produced in the plant tissues an increase of calcium and a decrease, of nitrogen, phosphorus and potassium. Although soil analysis indicated that available phosphorus increased with lime applications, total phosphorus in plant tissues decreased with each increment of lime ions in the soil solution. An applications of $\mathrm{P}$ with the increasing rates boosted linearly the dry matter content of the coffee seedlings $400 \mathrm{mg} \mathrm{P}, 600$ $\mathrm{mg} \mathrm{P}$ and $800 \mathrm{mg} \mathrm{P}$ rates showed linearly increments 0.440 , 0.533 and $0.657 \mathrm{~g}$ respectively (Figure 1). Phosphorus was one of the most limiting and an important nutrient for coffee, because it causes an increase in root development and plant vigor to ensure the formation of seedlings with high total dry matter contents [13-18]

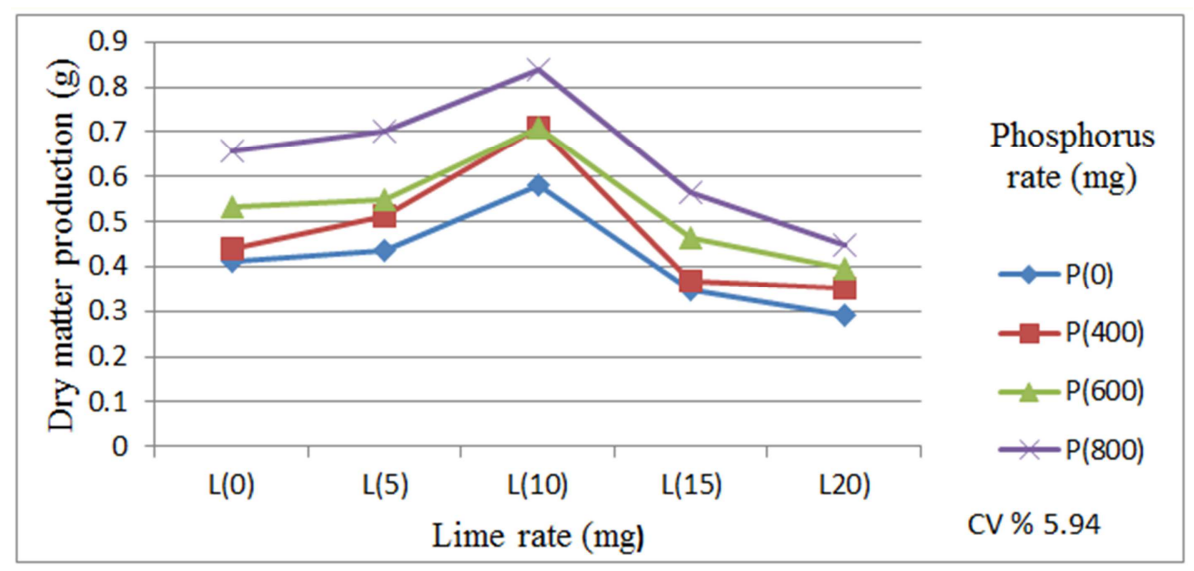

Figure 1. The interactions effects of lime and phosphorus rates on total dry matter productions.

\subsection{Leaf dry Mater Production and Partitioning}

Dry matter production and partitioning was one of the parameters which determine the ability of coffee seedlings to produce and allocate the dry biomass in to their leaf, stem and root parts. Lime and $\mathrm{P}$ rates and their interactions significantly affected leaf dry matter production and partitioning. The maximum leaf dry matter production partitioning (Figure 2) were recorded from the combined application of $10 \mathrm{~g}$ lime and $800 \mathrm{mg} P$ rate which gave $0.34 \mathrm{~g}$ dry matter and $50.70 \%$ partitioning respectively

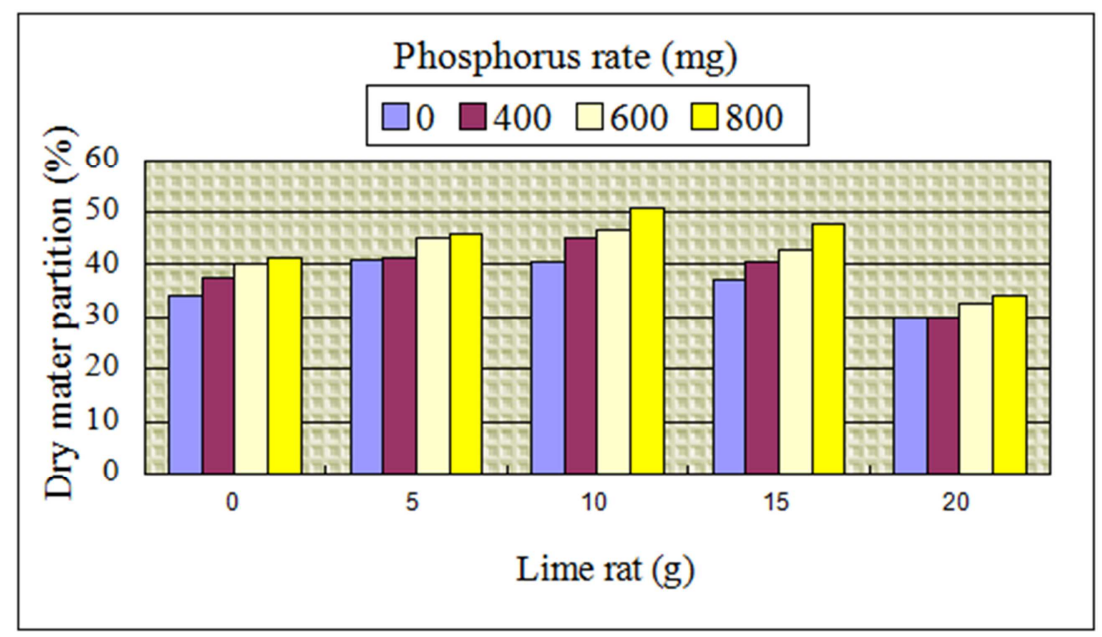

Figure 2. Effects of lime and phosphorus rates on leaf dry matter partitioning.

The applications of lime rates were enhance coffee seedlings leaf dry matter production and partitioning. Whereas lime rates 5 and $10 \mathrm{~g}$ gave $0.17 \mathrm{~g}$ and $0.26 \mathrm{~g}$ dry matter and 40.91 and $40.68 \%$ partitioning respectively. Further applications of lime 15 and $20 \mathrm{~g}$ contrary decreased to $0.13 \mathrm{~g}$ and $0.11 \mathrm{~g}$ dry matter and 37.14 and $29.73 \%$ partitioning (Figure 2 and Table 1). Similarly, leaf dry matter production and partitioning was affected by $\mathrm{P}$ rates.
Application of with increasing $\mathrm{P}$ rates enhances dry matter production and partitioning. Regarding to this $0.17,0.24$ and $0.32 \mathrm{~g}$ dry matter and $37.50,40.00$, and $41.27 \%$ partitioning observed from $400 \mathrm{mg} \mathrm{P}, 600 \mathrm{mg} \mathrm{P}$ and $800 \mathrm{mg}$ P treated plots respectively. Fageria and Baligar [12] reported that an application of $\mathrm{P}$ with the increasing rates improves leaf dry matter production and partitioning. 
Table 1. The interaction effect of lime and phosphorus rates on leaf dry matter production.

\begin{tabular}{lllll}
\hline \multirow{2}{*}{$\begin{array}{l}\text { Lime rates } \\
\text { g) }\end{array}$} & \multicolumn{4}{l}{ Phosphorus rate (mg) } \\
\cline { 2 - 5 } & $\mathbf{0}$ & $\mathbf{4 0 0}$ & $\mathbf{6 0 0}$ & $\mathbf{8 0 0}$ \\
\hline 0 & $0.16^{\text {gh }}$ & $0.17^{\text {gih }}$ & $0.24^{\text {efd }}$ & $0.32^{\text {ba }}$ \\
5 & $0.17^{\text {ih }}$ & $0.21^{\text {egfh }}$ & $0.27^{\text {egfh }}$ & $0.32^{\text {ab }}$ \\
10 & $0.26^{\text {ecd }}$ & $0.27^{\text {bcd }}$ & $0.32^{\text {ba }}$ & $0.34^{\mathrm{a}}$ \\
15 & $0.13^{\mathrm{ji}}$ & $0.15^{\mathrm{ji}}$ & $0.22^{\text {egfd }}$ & $0.29^{\text {bc }}$ \\
20 & $0.11^{\mathrm{j}}$ & $0.15^{\mathrm{ji}}$ & $0.17^{\text {gih }}$ & $0.20^{\text {ght }}$ \\
$\mathrm{CV} \% 12.40$ & & & & \\
\hline
\end{tabular}

Different letters within a column and row represent significant differences at $5 \%$ level

\subsection{Stem Dry Matter Production and Partitioning}

Stem dry matter production and partitioning significantly affected by lime and $\mathrm{P}$ rates and their interactions (Figure 3 and table 2). The maximum $0.27 \mathrm{~g}$ stem dry matter production and $30.99 \%$ partitioning were recorded from the plot $10 \mathrm{~g}$ lime and $800 \mathrm{mg}$. Whereas 10 and $15 \mathrm{~g}$ lime rates applied plot showed 0.12 and $0.15 \mathrm{~g}$ stem dry matter and 27.27 and $23.94 \%$ partitioning respectively.

Table 2. The interaction effects of lime and phosphorus rates on stem dry matter production and partition.

\begin{tabular}{lllll}
\hline \multirow{2}{*}{$\begin{array}{l}\text { Lime rates } \\
\text { (g) }\end{array}$} & \multicolumn{4}{l}{ Phosphorus rate $(\mathbf{m g})$} \\
\cline { 2 - 5 } & $\mathbf{0}$ & $\mathbf{4 0 0}$ & $\mathbf{6 0 0}$ & $\mathbf{8 0 0}$ \\
\hline 0 & $0.10^{\mathrm{kl}}$ & $0.12^{\mathrm{hji}}$ & $0.13^{\mathrm{hg}}$ & $0.15^{\mathrm{fe}}$ \\
5 & $0.12^{\mathrm{hji}}$ & $0.15^{\mathrm{fe}}$ & $0.16^{\mathrm{de}}$ & $0.17^{\mathrm{dc}}$ \\
10 & $0.15^{\mathrm{fe}}$ & $0.17^{\mathrm{c}}$ & $0.20^{\mathrm{b}}$ & $0.27^{\mathrm{a}}$ \\
15 & $0.10^{\mathrm{kl}}$ & $0.11^{\mathrm{kl}}$ & $0.11^{\mathrm{kji}}$ & $0.13^{\mathrm{hgi}}$ \\
20 & $0.08^{\mathrm{m}}$ & $0.09^{1}$ & $0.11^{\mathrm{kjl}}$ & $0.11^{\mathrm{kji}}$ \\
CV \% 5.78 & & & & \\
\hline
\end{tabular}

Different letters within a column and row represent significant differences at $5 \%$ level

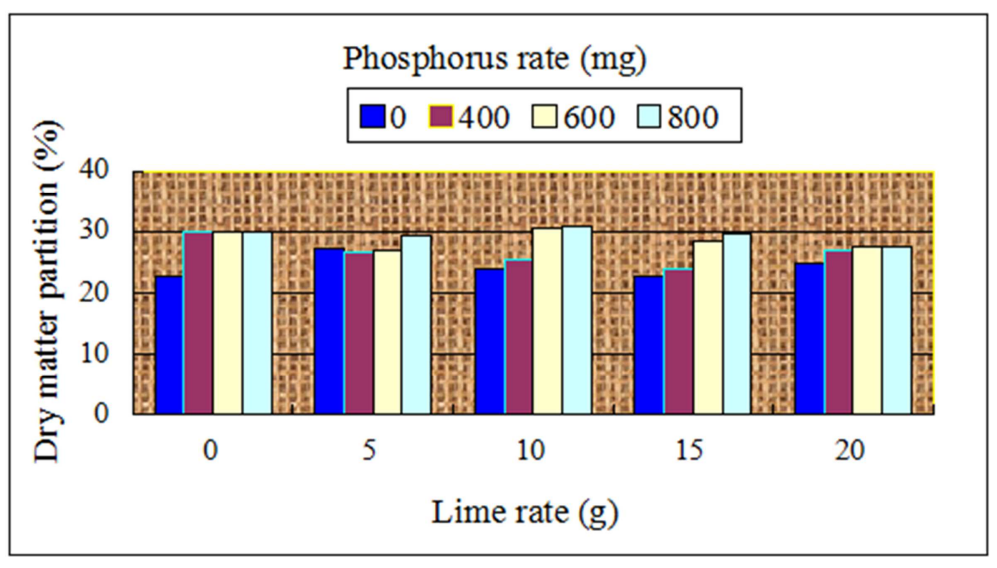

Figure 3. Effects of lime and phosphorus rates on Stem dry matter partitioning.

Although an application of $\mathrm{P}$ rates treatments showed an increasing rate of stem dry mater production partitioning linearly with increasing applied P rates. Regarding to this $0.12,0.13$ and $0.15 \mathrm{~g}$ dry matter and $22.73,30.00$ and $30.16 \%$ partitioning observed from $400 \mathrm{mg}$ P, $600 \mathrm{mg} \mathrm{P}$ and $800 \mathrm{mg}$ P treated plots respectively. This was confirmed with the works of Anteneh [3] reported that applications of $\mathrm{P}$ with the increasing rates enhance stem dray matter production and partitioning.

\subsection{Root Dry Matter Production and Partitioning}

Lime and $\mathrm{P}$ rates and their interactions showed statically significance difference among the treatments (Figure 4 and Table 3). The maximum 0.27 root dry matter production and $23.94 \%$ Partitioning recorded from $20 \mathrm{~g}$ lime and $800 \mathrm{mg} \mathrm{P}$ rate respectively.

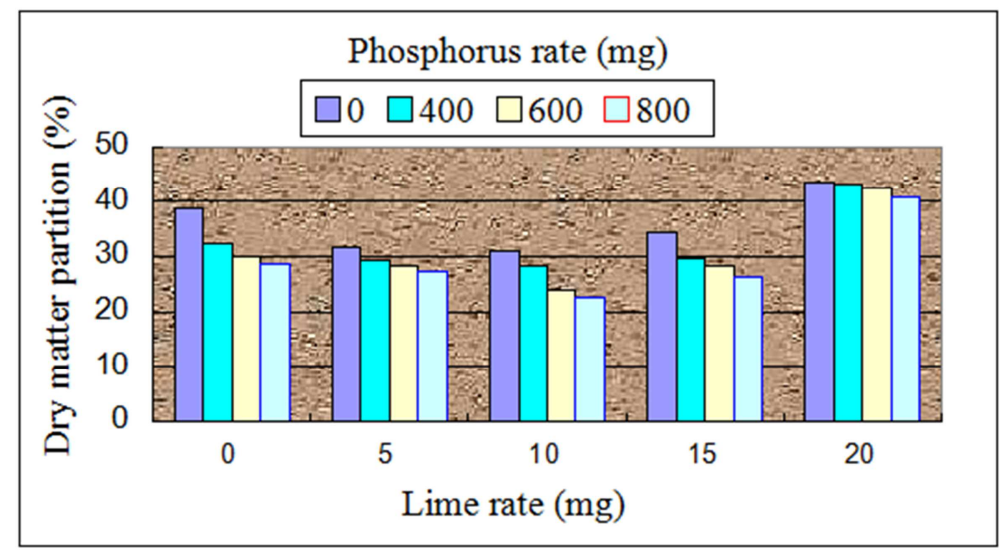

Figure 4. Effects of lime and phosphorus rates on root dry matter partitioning. 
However application of 5 and $10 \mathrm{~g}$ lime rates showed dramatically increased root dry mater production 0.15 and $0.17 \mathrm{~g}$ productions and decreased partitioning 31.82 to $30.90 \%$ respectively. Further addition rates from $15 \mathrm{~g}$ to 20 $\mathrm{g}$ which gave 0.12 and $0.10 \mathrm{~g}$ production and increased 34.29 to $43.3 \%$ partitioning respectively.

Table 3. The interaction effect of lime and phosphorus rates on root dry matter production and partition.

\begin{tabular}{lllll}
\hline \multirow{2}{*}{$\begin{array}{l}\text { Lime rates } \\
\text { (g) }\end{array}$} & \multicolumn{4}{l}{ Phosphorus rate $(\mathbf{m g})$} \\
\cline { 2 - 5 } & $\mathbf{0}$ & $\mathbf{4 0 0}$ & $\mathbf{6 0 0}$ & $\mathbf{8 0 0}$ \\
\hline 0 & $0.13^{\mathrm{ih}}$ & $0.15^{\mathrm{hg}}$ & $0.16^{\mathrm{feg}}$ & $0.20^{\mathrm{d}}$ \\
5 & $0.15^{\mathrm{hg}}$ & $0.15^{\mathrm{fg}}$ & $0.17^{\mathrm{e}}$ & $0.21^{\mathrm{dc}}$ \\
10 & $0.17^{\text {fe }}$ & $0.22^{\mathrm{c}}$ & $0.24^{\mathrm{b}}$ & $0.27^{\mathrm{a}}$ \\
15 & $0.12^{\mathrm{i}}$ & $0.11^{\mathrm{ij}}$ & $0.13^{\text {ih }}$ & $0.15^{\mathrm{hg}}$ \\
20 & $0.10^{\mathrm{j}}$ & $0.10^{\mathrm{j}}$ & $0.11^{\mathrm{ij}}$ & $0.13^{\text {ih }}$ \\
$\mathrm{CV} \% 7.01$ & & & & \\
\hline
\end{tabular}

Different letters within a column and row represent significant differences at $5 \%$ level

Root dry matter partitioning was enhanced with various $\mathrm{P}$ rates. Although application of $400 \mathrm{mg} \mathrm{P}, 600 \mathrm{mg} \mathrm{P}$ and 800 $\mathrm{mg} \mathrm{P}$ rates showed linearly increasing dry matter $0.15,0.16$ and $0.20 \mathrm{~g}$ productions and contrary decreasing $32.50,30.00$ and $28.57 \%$ dry matter partitioning. Coffee root dry matter partition one of the most important parameters which showed the ability of the seedlings to distribute the dry matter part across to their root parts. Anteneh [3] reported that the increase in dry matter partitioned to roots with increasing lime rate could be attributed to the impaired chemical characteristics of the soil, such as increase in $\mathrm{pH}$ and decrease in available P. This finding agrees with the findings of Taye et al. [19] reported enhanced partitioning of the total; assimilate to roots of coffee seedlings under relatively nutrient deficient and poor physical media condition. This depicts that root is much stronger sink of the total assimilate under relatively nutrient stressed condition.

\subsection{Shoot to Root Ratio}

Lime and $\mathrm{P}$ rates and their interactions improved shoot to root ratio of coffee seedlings (Figure 5). The combined effects of lime and phosphorus treated plot showed the highest coffee seedling shoot to root growth rate as compared to lime and $\mathrm{P}$ alone plots (Figure 5). Accordingly the highest shoot to root ratio $3.40 \%$ recorded from combined lime and phosphorus treatments of $10 \mathrm{~g}$ lime and $800 \mathrm{mg}$ phosphorus rates. The similar work also reported by Taye [20] showed that, high quality coffee seedlings with balanced shoot to root ratio need to be produced under optimum soil environments.

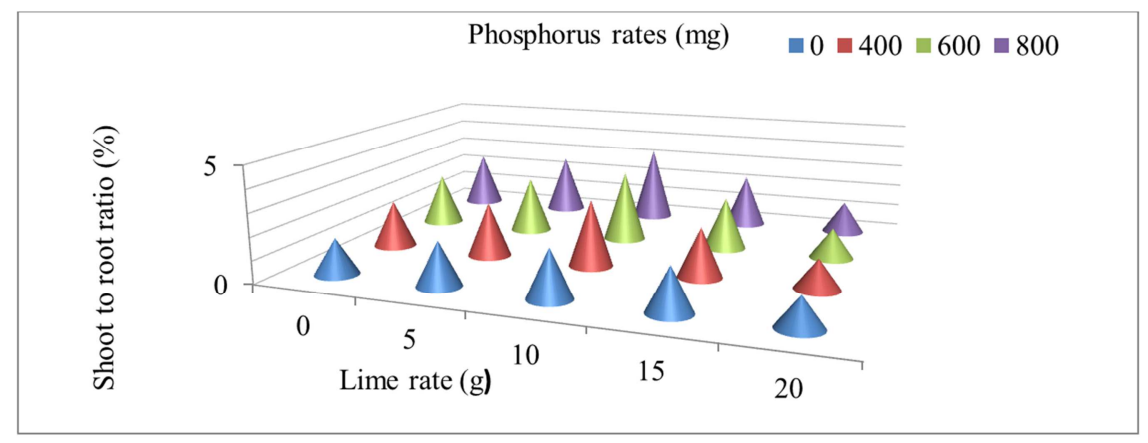

Figure 5. The combined effects of lime and phosphorus rates on shoot to root ratio.

The lowest 1.31 shoot with root ratio was recorded from 1.31 shoot to root ratio recorded from $20 \mathrm{~g}$ lime treated plots. Fageria and Baligar [12] reported that over applications of lime leads to at highest Phosphorus fertilizers was fixed by $\mathrm{Ca}^{+2}$ and retarded the growth of the coffee seedlings, this is due to the roots share more of the total assimilates than the shoot and subsequently leading to a typical decrease in shoot to root dry matter ratio. Although lime applied treatments $5 \mathrm{~g}$, $10 \mathrm{~g}$ showed 1.95 and 2.14 shoot to root ratio further applications $15 \mathrm{~g}$ and $20 \mathrm{~g}$ decreasing 1.92 and 1.31 shoot to root ratio. The response of $400 \mathrm{mg} \mathrm{P}, 600 \mathrm{mg} \mathrm{P}$ and $800 \mathrm{mg} P$ rates showed that there was linearly increment $2.08,2.33$ and 2.50 of shoot to root ratio (Figure 5).

\section{Conclusion}

Soil acidity is one of the major problems that significantly lower the productivity of many cultivated soils in south west Ethiopia especially in area of high rain fall. Soil acidity is characterized by low $\mathrm{pH}$ and the abundance of acidic cations $(\mathrm{H}, \mathrm{Al}, \mathrm{Fe}$, and $\mathrm{Mn})$ on system colloid soil solution. The low $\mathrm{pH}$ affects significantly the fixation and the availability of soil nutrients such as available phosphorous and basic cations. The abundance of acidic cations on system colloid soil solution can be toxic to crop growth and leads to reduced crop yield. Soil acidity can be amended by adding liming materials to the soil Reductions in the dry matter production of shoots and roots and in the shoot/root ratio in the coffee seedlings, $\mathrm{Al}^{3+}$ accumulated in the roots and a small part of it was translocated to the aerial part. The research activity was conducted to evaluate the response of lime and phosphorus rates on dry matter production and partitioning of hybrid coffee seedlings under acidic nursery media at Jimma south west Ethiopia. The result revealed that the maximum dry matter production, portioning and shoot to root ratio were recorded from $10 \mathrm{~g}$ lime and $800 \mathrm{mg}$ Phosphorus rates 2.5 $\mathrm{Kg}_{-}{ }^{1}$ soil This increment in dry matter of coffee seedlings with application of $\mathrm{P}$ fertilizer might be due to the adequate 
supply of $\mathrm{P}$ could be attributed to an increase the dry matter contents of the seedlings. This in turn increased photosynthetic area which demonstrates a strong correlation with dry matter accumulation and yield. Increased dry matter yield of coffee seedlings due to liming is attributed to the beneficial effect of ameliorating the soil, which increased the Ca-saturation and availability of major nutrients, especially phosphorus and other basic cations. In general $10 \mathrm{~g}$ lime and $800 \mathrm{mg}$ phosphorus rates gave better dry matter production, partitioning and shoot to root ratio which contribute for vigorous and healthy coffee seedlings to transplant for the main filed.

\section{References}

[1] Achalu Chimdi, 2014. Assessment of the Severity of Acid Saturations on Soils Collected from Cultivated Lands of East Wollega Zone, Ethiopia. Science, Technology and Arts Research Journal, 3 (4): 42-48.

[2] Achalu Chimdi, Heluf Gebrekidan, Kibebew Kibret and Abi Tadesse, 2012, Response of barley to liming of acid soils collected from different land use systems of Western Oromia, Ethiopia, Ethiopia. Journal of Biodiversity and Environmental Sciences, 2 (7): 1-13.

[3] Anteneh Netsere, 2015. Dry Matter Production and Partitioning in Arabica Coffee Seedling as Affected by Lime and Phosphorus Mineral Fertilizer at Jimma, Southwestern Ethiopia. Journal of Biology, Agriculture and Healthcare, 13: 95-101.

[4] Cambrony, H. R. 1992. Coffee growing. CTA/The Macamallian Press Ltd., New York, Tokyo119 pp.

[5] Cyamweshi, R. A., J. S. Tenywa, P. Ebanyat, M. M. Tenywa, A. Mukuralinda and A. Nduwumuremyi, 2013. Phosphate Sorption Characteristics of Andosols of the Volcanic Highlands of Central African Great Lakes Region. Journal of Environmental Science and Engineering, 2: 89-96.

[6] DaMatta, F., M. 2004. Ecophysiological constraints on the production of shaded and unshaded coffee: a review. Field crop research. 86: 99-114.

[7] DeWispelaere, L., V. Marcelino, A. Regassa, E. De Grave, M. Dumon, F. Mees and E. Van Ranst, 2015. Revisiting nitic horizon properties of Nitisols in SW Ethiopia. Geoderma, 243: 69-79.

[8] Emana, B. T., 2015. Distribution assessment and pathogenicity test of coffee berry disease (Colletotrichum kahawae) in Hararghe, Ethiopia, 2: 038-042.

[9] Ericcson, T. and T. Ingested, 1988. Nutrition and growth of birch seedlings at varied relative phosphorus addition rates. Journal of Plant Physiology, 72 (2): 227-235.
[10] Eyasu Elias, 2017. Characteristics of Nitisol profiles as affected by land use type and slope class in some Ethiopian highlands. Journal of Environ Syst Res., (6) 20: 1-15.

[11] Fageria, N. K. and A. Moreira, 2011. The Role of Mineral Nutrition on Root Growth of Crop Plants. Advances in agronomy, 110 (1): 251-331.

[12] Fageria, N. K. and V. C. Baligar, 2008. Ameliorating soil acidity of tropical Oxisols by liming for sustainable crop production, Advances in agronomy, 99: 345-399.

[13] Habtamu Admas, 2015. Reclamation of Phosphorus Fixation by Organic Matter in Acidic Soils. Global journal of agricultural science 3 (6): 271-78.

[14] ICO (International coffee organization), 2018. Coffee market report in the international trade, challenges and opportunities facing the sector, pp. 1-8.

[15] Kamprath, E. J., 1984. Crop response to lime on soils in the tropics. Soil acidity and liming, (soilacidityandl), pp. 349-368.

[16] Naidu, R., R. W. Tillman, J. K. Syers and J. H. Kirkman, 1990. Lime-aluminium-phosphorus interactions and the growth of Leucaena leucocephala. I plant growth Plant and Soil, 126 (1): 9-17.

[17] Paulos Dubale, 1994. Mineral Fertilizer of Coffee in Ethiopia. Institute of Agricultural Research, Addis Ababa, Ethiopia. $105 \mathrm{p}$.

[18] Silva, L. D., P. E. Marchiori, C. P. Maciel, E. C. Machado and R. V. Ribeiro, 2010. Photosynthesis, water relations and growth of young coffee plants according to phosphorus availability. Pesquisa Agropecuária Brasileira, 45 (9): 965972.

[19] Taye Kufa 2012. Biomass production and distribution in seedlings of Coffea arabica L. genotypes under contrasting nursery environments in southwestern Ethiopia Agricultural Sciences (3) 6: 835-843.

[20] Taye Kufa, 1998. Response of arebica coffee (Coffea arebica L.) to various soil fertility management M. Sc thesis, Alemeya university of Agriculture, pp. 127.

[21] Tekalign Mamo and I. Haque. 1991. Phosphorus status of some Ethiopian soils. III. Evaluation of some soil test methods for available phosphorus. Tropical Agriculture (Trinidad), 68: $51-56$

[22] Tesfaye Shimber, Alemseged Yilma, Taye Kufa, Endale Taye and Anteneh Netsere, 2005. Coffee seedlings management and production. Amharic version, Ethiopian Agricultural Research Organization, Addis Ababa, Ethiopia. 17pp.

[23] Yacob Edjamo, Taye Kufa and Alemseged Yilma, 1995. Varietal and age impact on Arabica coffee leaf growth parameters at three locations. Pp. 38-51. In: Proceedings of the Third Conference of the Agronomy and Crop Physiology Society of Ethiopia, 29-30 May 1997, Institute of Agricultural Research, Addis Ababa, Ethiopia. 